\section{Treatment with Hydrogen Peroxide and Seedcoat Removal or Clipping Improve Germination of 'Genesis' Triploid Watermelon}

\author{
John R. Duval ${ }^{1}$ \\ GCREC-Dover, University of Florida, Dover, FL 33527 \\ D. Scott NeSmith ${ }^{2}$
Department ofHorticulture, Georgia Experiment Station, University of Georgia,
Griffin, GA 30223
}

Additional index words. Citrullus lanatus, seedless watermelon

\begin{abstract}
Seeds of triploid watermelons [Citrullus lanatus (Thunb.) Matsum \& Nakai] often germinate poorly, which prevents adequate stand establishment in both field and greenhouse environments. Methods of improving germination and emergence of these expensive seeds would reduce overall risk to growers, thus increasing the crop's market prominence. Seeds of 'Genesis' triploid watermelon were subjected to three treatments: 1) seedcoat removal; 2) clipping the seedcoat opposite the radicle end; or 3) no seedcoat alteration; and were germinated on agar in the presence of a $0 \%, 1 \%, 2 \%, 4 \%$, or $8 \%$ aqueous $\mathrm{H}_{2} \mathrm{O}_{2}$ at constant $28{ }^{\circ} \mathrm{C}$ in the dark. Seedcoat removal, clipping, and all levels of $\mathrm{H}_{2} \mathrm{O}_{2}$ increased final germination percentages relative to the control (no seedcoat alteration, no $\mathrm{H}_{2} \mathrm{O}_{2}$ ) by as much as $70 \%$. Hydrogen peroxide levels $>2 \%$ resulted in severe injury to germinating seeds. These findings suggest that germination barriers of triploid watermelon are seedcoat related, and that seedcoat alteration and $\mathrm{H}_{2} \mathrm{O}_{2}$ can overcome these barriers.
\end{abstract}

Triploid watermelon seeds often exhibit poor germination and emergence. Kihara (1951) reported that triploid seedcoats are hard and thick, like those of their tetraploid parent, and this may inhibit germination. The author further suggested that removing part of the seedcoat should improve germination. Splitting the seedcoat of tetraploid watermelons laterally improved germination (Nerson et al., 1985). Recently, Duval and NeSmith(1999) confirmed that mechanical scarification improved and increased the consistency of emergence of 'Genesis' triploid watermelon; however, emergence was still not at an acceptable level. Alternative mechanical pretreatments, with or without chemical treatment, of triploid watermelon seed could improve germination and stand establishment.

Hydrogen peroxide $\left(\mathrm{H}_{2} \mathrm{O}_{2}\right)$ has been reported to improve germination of seeds of Vagueria infausta Robyns. (Msanga and Maghembe, 1989), Paspalum distichum L. (Huang and Hsiao, 1987), Fragaria $\times$ ananassa

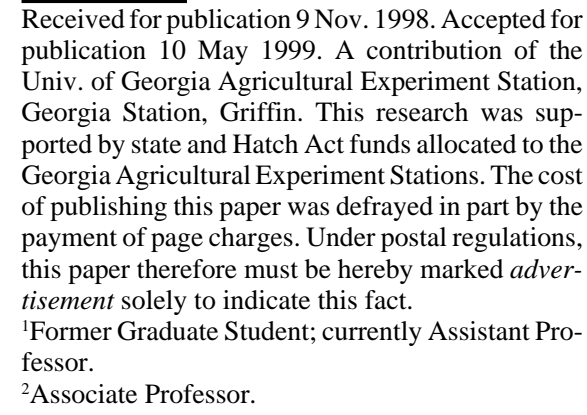
publication 10 May 1999. A contribution of the Univ. of Georgia Agricultural Experiment Station, Georgia Station, Griffin. This research was supported by state and Hatch Act funds allocated to the Georgia Agricultural Experiment Stations. The cost of publishing this paper was defrayed in part by the payment of page charges. Under postal regulations, this paper therefore must be hereby marked advertisement solely to indicate this fact.

${ }^{1}$ Former Graduate Student; currently Assistant Professor.

${ }^{2}$ Associate Professor.

Duch. (Negi and Singh, 1972), Anthyllis cytisoides L. (Ibanez and Passera, 1997), Tripsacum dactyloides L. (Kindiger, 1994), and Cinnamomum camphora L. (Chien and Lin, 1994). Successful methods were highly variable and ranged from seeds being soaked in high $\mathrm{H}_{2} \mathrm{O}_{2}$ concentrations (30\%) for short periods of time ( $2 \mathrm{~h}$ ) to germination of seeds in solutions of low $\mathrm{H}_{2} \mathrm{O}_{2}$ concentrations $(1 \%)$. These studies suggest that $\mathrm{H}_{2} \mathrm{O}_{2}$ can be beneficial in promoting germination of hard-seeded species. This research was conducted to determine the effectiveness of seedcoat alteration and $\mathrm{H}_{2} \mathrm{O}_{2}$ treatments on improving germination dynamics of triploid watermelon.

\section{Materials and Methods}

'Genesis' seeds (Shamrock Seed Co., Salinas, Calif.) were purchased for use in various seed treatment tests. Six hundred seeds were surfaced sterilized by placing them in a 1-L beaker with $500 \mathrm{~mL}$ of $1 \% \mathrm{NaOCl}$ for $5 \mathrm{~min}$ with constant stirring. After sterilization, seeds were rinsed thoroughly under running tap water for $5 \mathrm{~min}$. A $3 \times 5$ factorial experimunt was established with two methods of seedcoat alteration, plus unaltered seed, and five levels of $\mathrm{H}_{2} \mathrm{O}_{2}$. Seedcoat alterations included clipped seedcoats and excised embryos. Clipping consisted of using common nail clippers to remove a portion of the seedcoat opposite the radicle end, resulting in an opening $\approx 3 \times 1 \mathrm{~mm}$. Embryos were excised by carefully splitting the seedcoat and gently prying it away from the embryo and cotyledons. They were not surfaced sterilized. Following seedcoat alteration, seeds were placed on $20 \mathrm{~mL}$ of a $0.8 \%$ $(\mathrm{w} / \mathrm{v})$ sterile agar media in $100 \times 15 \mathrm{~mm}$ petri dishes. Five milliliters of a $0 \%, 1 \%, 2 \%, 4 \%$, or $8 \% \mathrm{H}_{2} \mathrm{O}_{2}$ solution (J.T. Baker Chemical Co., Phillipsburg, N.J.) were added to the petri dishes and allowed to remain in the dish throughout the experiment. Five dishes containing 10 seeds each for each seedcoat alteration and $\mathrm{H}_{2} \mathrm{O}_{2}$ treatment combination were used in each of three experiments. Each experiment was considered a replication. For each replication, dishes were placed in a dark growth chamber (model E15; Conviron, Pembina, N.Dak.) at $28 \pm 0.5^{\circ} \mathrm{C}$. Germination data were taken daily for $10 \mathrm{~d}$ (the point at which no additional germination over three consecutive days was observed). Seeds were considered germinated when the radicle had protruded $2 \mathrm{~mm}$. Seed quality was rated after $7 \mathrm{~d}$ in the chambers. Quality of each seed was assessed on a 1 to 10 scale, with 1 being the lowest rating and 10 the highest. Quality points were deducted from growing seedlings for stunted growth, discoloration, and other abnormalities.

Germination data were modeled and analyzed using the following logistic function (Eq. 1) (SAS Institute, 1990):

$$
\mathrm{Y}=\frac{\beta_{0}}{1+[(1-\mathrm{p}) / \mathrm{p}] e^{-\beta_{1}\left(\mathrm{day}-\beta_{2}\right)}}
$$

Where $\beta_{0}=$ asymptote of final germination percentage, $\beta_{1}=$ relative rate of germination, $\beta_{2}=$ time until asymptote of $\mathrm{p}$ is reached, and $\mathrm{p}=$ point where a predetermined value of maximal germination is obtained (90\%).

Significant differences among parameters were determined based upon $95 \%$ confidence intervals. Seed quality data were subjected to linear and quadratic analysis.

\section{Results and Discussion}

Significant interactions between seedcoat and $\mathrm{H}_{2} \mathrm{O}_{2}$ were detected $(P \leq 0.01)$ for germination; thus, data are presented for the different seedcoat alteration methods at each level of $\mathrm{H}_{2} \mathrm{O}_{2}$ (Table 1). Final germination percentage in water alone (Fig. 1a, Table 1) was higher for embryos than for clipped seeds and lowest for intact seeds. No differences were observed among treatments in relative rate of germination or in time until $90 \%$ of maximum germination was reached.

At $1 \% \mathrm{H}_{2} \mathrm{O}_{2}$, final germination percentage for clipped seeds was significantly less than for excised embryos or intact seeds (Fig. 1b, Table 1). Other model parameters were nonsignificant. No differences among seedcoat treatments were significant at the $2 \%$ concentration of $\mathrm{H}_{2} \mathrm{O}_{2}$ (Fig. 1c, Table 1). Final germination percentage of intact seeds was greatly enhanced by all concentrations of $\mathrm{H}_{2} \mathrm{O}_{2}$ (Fig. 1 ), although $8 \%$ was less effective than lower concentrations.

When $4 \% \mathrm{H}_{2} \mathrm{O}_{2}$ was applied, toxic effects became evident. Germination percentage of embryos was lower than that of clipped or intact seeds (Fig. 1d, Table 1). No other differ- 

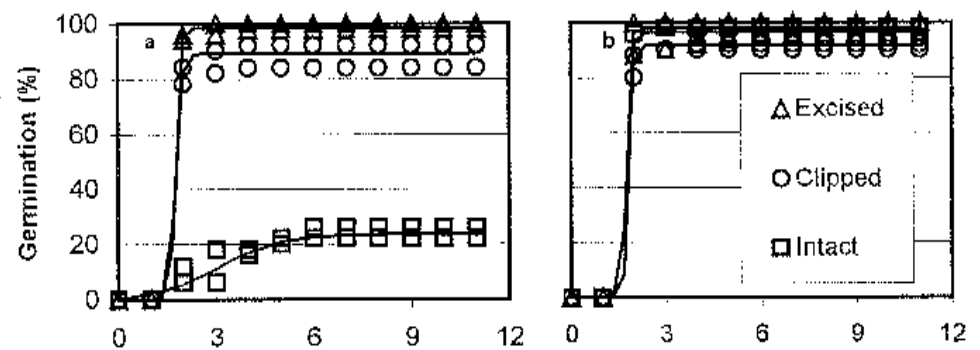

Table 1. Model parameter estimates for germination of 'Genesis' triploid watermelon after seedcoat alteration and exposure to hydrogen peroxide.
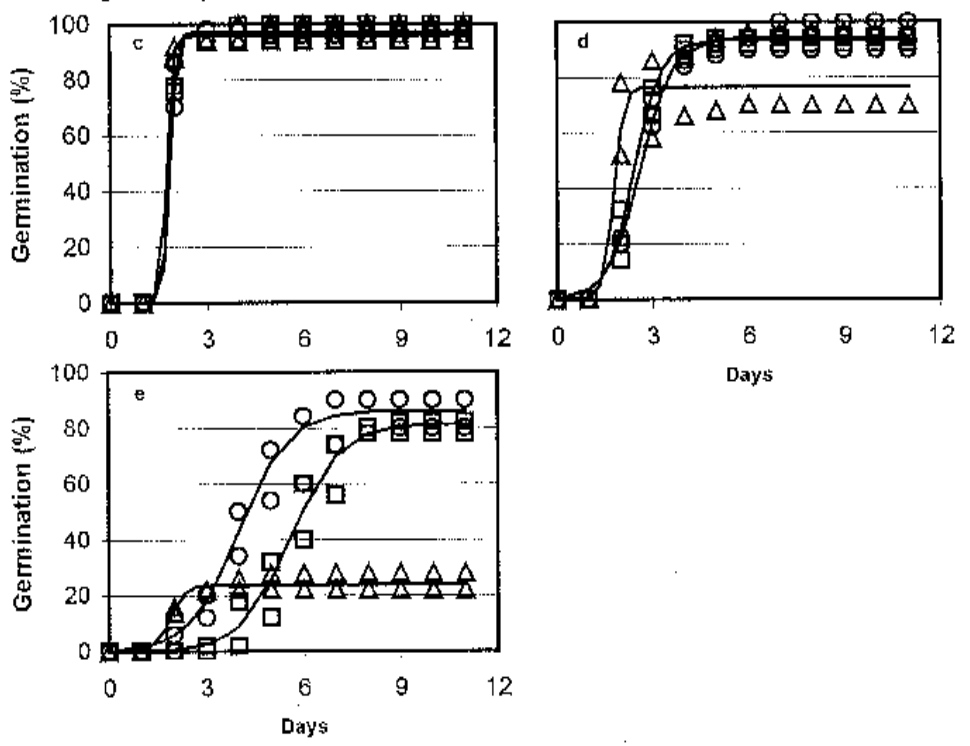

\begin{tabular}{lcccc}
\hline \hline & $\beta_{0}{ }^{\mathrm{z}}$ & $\beta_{1}{ }^{\mathrm{y}}$ & $\beta_{2}{ }^{\mathrm{w}}$ & $r^{2}$ \\
\hline & \multicolumn{5}{c}{$0 \% \mathrm{H}_{2} \mathrm{O}_{2}$} \\
Excised embryo & $98.5 \mathrm{a}^{\mathrm{x}}$ & $14.0 \mathrm{a}$ & $1.9 \mathrm{a}$ & 0.99 \\
Clipped & $89.1 \mathrm{~b}$ & $10.0 \mathrm{a}$ & $2.0 \mathrm{a}$ & 0.98 \\
Intact seed & $23.6 \mathrm{c}$ & $1.1 \mathrm{a}$ & $5.2 \mathrm{a}$ & 0.90 \\
& \multicolumn{5}{c}{$1 \% \mathrm{H}_{2} \mathrm{O}_{2}$} \\
Excised embryo & $96.4 \mathrm{a}$ & $16.1 \mathrm{a}$ & $1.9 \mathrm{a}$ & 0.99 \\
Clipped & $91.6 \mathrm{~b}$ & $11.1 \mathrm{a}$ & $2.0 \mathrm{a}$ & 0.99 \\
Intact seed & $98.0 \mathrm{a}$ & $14.8 \mathrm{a}$ & $1.9 \mathrm{a}$ & 0.99 \\
& \multicolumn{5}{c}{$2 \% \mathrm{H}_{2} \mathrm{O}_{2}$} \\
Excised embryo & $95.8 \mathrm{a}$ & $11.0 \mathrm{a}$ & $1.9 \mathrm{a}$ & 0.99 \\
Clipped & $97.2 \mathrm{a}$ & $9.5 \mathrm{a}$ & $2.1 \mathrm{a}$ & 0.99 \\
Intact seed & $95.8 \mathrm{a}$ & $9.9 \mathrm{a}$ & $2.1 \mathrm{a}$ & 0.99 \\
& \multicolumn{5}{c}{$4 \% \mathrm{H}_{2} \mathrm{O}_{2}$} & & \\
Excised embryo & $76.6 \mathrm{a}$ & $6.1 \mathrm{a}$ & $2.1 \mathrm{a}$ & 0.77 \\
Clipped & $94.4 \mathrm{~b}$ & $1.9 \mathrm{a}$ & $3.8 \mathrm{a}$ & 0.98 \\
Intact seed & $93.4 \mathrm{~b}$ & $2.3 \mathrm{a}$ & $3.4 \mathrm{a}$ & 0.99 \\
& \multicolumn{5}{c}{$8 \% \mathrm{H}_{2} \mathrm{O}_{2}$} & & \\
Excised embryo & $23.7 \mathrm{a}$ & $4.1 \mathrm{a}$ & $2.4 \mathrm{a}$ & 0.90 \\
Clipped & $86.1 \mathrm{~b}$ & $1.3 \mathrm{a}$ & $5.8 \mathrm{~b}$ & 0.96 \\
Intact seed & $81.3 \mathrm{~b}$ & $1.3 \mathrm{a}$ & $7.3 \mathrm{c}$ & 0.97
\end{tabular}

${ }^{\mathrm{z}}$ Asymptote of final emergence percentage.

${ }^{y}$ Relative rate of emergence.

wTime (days) until asymptote of $90 \%$ emergence is reached.

${ }^{x}$ Parameter separation among seedcoat treatments within each level of $\mathrm{H}_{2} \mathrm{O}_{2}$. Parameter separation determined by $95 \%$ confidence intervals.

In conclusion, clipping, removing the

Fig. 1 (a-e). Germination of excised embryos, clipped, and intact seeds exposed to (a) $0 \%$, (b) $1 \%$, (c) $2 \%$, (d) $4 \%$, or (e) $8 \% \mathrm{H}_{2} \mathrm{O}_{2}$. Lines representative of modeled germination. Symbols represent individual data points from 3 experiments. Many points maybe hidden by overlapping. Model parameter estimates can be found in Table 1 .

ences were noted. The highest level of $\mathrm{H}_{2} \mathrm{O}_{2}$ $(8 \%)$ was detrimental to all seeds (Fig. 1e, Table 1). Final germination percentage was lower for embryos than for either clipped or intact seeds, and time to reach $90 \%$ of final germination was significantly different among treatments (naked < clipped < intact). No differences in relative rate of germination were observed.

Incidence of abnormal seedling growth increased with increasing $\mathrm{H}_{2} \mathrm{O}_{2}$ concentration for all seedcoat treatments (data not shown). Analysis showed significant linear $(P \leq 0.01)$ and quadratic $(P \leq 0.01)$ effects of increasing concentrations of $\mathrm{H}_{2} \mathrm{O}_{2}$. Radicle damage (browning, cracking of the epidermis, and lack of elongation after protrusion from the seedcoat) at $\mathrm{H}_{2} \mathrm{O}_{2}$ levels of $2 \%$ and $4 \%$ was very pronounced. At $8 \% \mathrm{H}_{2} \mathrm{O}_{2}$ severe bleaching of tissue occurred and radicles failed to elongate more than $3 \mathrm{~mm}$.

Clipping the seeds or completely removing the seedcoat apparently relieved any mechanical restraint and/or barriers to gas exchange, as these treatments greatly improved germination of 'Genesis' when compared to the intact seeds in water. This evidence suggests that any barriers hindering triploid watermelon germination are associated with the seedcoat. Germination of intact seeds in $1 \%$ or $2 \% \mathrm{H}_{2} \mathrm{O}_{2}$ equaled that of other seed treatments, and far exceeded germination of intact seeds in the absence of $\mathrm{H}_{2} \mathrm{O}_{2}$. This improved germination in the presence of $1 \%$ or $2 \% \mathrm{H}_{2} \mathrm{O}_{2}$ may result from weakening of the seedcoat or from evolution of $\mathrm{O}_{2}$ as $\mathrm{H}_{2} \mathrm{O}_{2}$ reacts with the seeds. In Camphora (Chien and Lin, 1994) seed cracking along the hilum was observed when seeds were exposed to $15 \% \mathrm{H}_{2} \mathrm{O}_{2}$ for $25 \mathrm{~min}$. Chien and Lin proposed that this weakening of the seedcoat enhanced germination. Cracking was not observed for the triploid watermelon seedcoats in the current experiment. Nerson et al. (1985) discounted $\mathrm{O}_{2}$ impermeability of the seedcoats of tetraploid watermelon as the barrier to germination based on responses in aerated vs. non-aerated solutions. Hydrogen peroxide has been evaluated as an additive to polymer gels for seeding cotton with a hydraulic planter (Bordovsky et al., 1991). It was discovered that peroxide reacted with seeds and, to a lesser extent, the starch in the planting gel to produce $\mathrm{O}_{2}$. Bordovsky et al. (1991) concluded the amount of $\mathrm{O}_{2}$ produced was sufficient to meet the respiration requirements of cotton seeds in a polymer gel. Evolution of $\mathrm{O}_{2}$ from $\mathrm{H}_{2} \mathrm{O}_{2}$ in the current study would have enriched the atmosphere within the closed petri dish, and the increased $\mathrm{O}_{2}$ concentration might have favored its diffusion through the seedcoat. In addition, the $\mathrm{H}_{2} \mathrm{O}_{2}$ that was absorbed by the seed and reacted within the seed itself could supply $\mathrm{O}_{2}$ directly to the growing embryo. At concentrations $>1 \% \mathrm{H}_{2} \mathrm{O}_{2}$, significant damage to growing seedlings negated any benefit in germination rate. Therefore, longterm seed exposure to concentrations $>1 \% \mathrm{H}_{2} \mathrm{O}_{2}$ should not be considered. seedcoat, and the presence of $\mathrm{H}_{2} \mathrm{O}_{2}$ greatly enhanced the germination of 'Genesis' triploid watermelon seed. Further research needs to be conducted to determine the permeability of triploid watermelon seedcoats to $\mathrm{O}_{2}$. Also, the practicality of seed pretreatments, such as priming to enhance germination in a production setting, need to be explored.

\section{Literature Cited}

Bordovsky, J.P., W.M. Lyle, and A.P. Onken. 1991. Cottonseed preparation for hydraulic planter. Agron. J. 83:275-278.

Chien, H. and T.P. Lin. 1994. Mechanism of hydrogen peroxide in improving the germination of Cinnamomum camphora seed. Seed Sci. Technol. 22:231-236.

Duval, J.R. and D.S. NeSmith. 1999. Emergence of 'Genesis' triploid watermelon following mechanical scarification. J. Amer. Soc. Hort. Sci. 124:430-432.

Huang, W.Z. and A.I. Hsaio. 1987. Factors affecting seed dormancy and germination of Paspalum distichum. Seed Res. 27:405-415.

Ibanez, A.N. and C.B. Passera. 1997. Factors affecting the germination of albaida (Anthyllis cytisoides L.), a forage legume of the Mediterranean coast. J. Arid Envir. 35:225-231.

Kihara, H. 1951. Triploid watermelons. Proc. Amer. Soc. Hort. Sci. 58:217-230.

Kindiger, B. 1994. A method to enhance germination of eastern gamagrass. Maydica 39:53-56.

Msanga, H.P. and J.A. Maghembe. 1989. Physical scarification and hydrogen peroxide treatment improves germination of Vangueria infausta seed. For. Ecol. \& Mgt. 28:301-308.

Negi, S.P. and R. Singh. 1972. Effect of different chemicals on germination of strawberry seeds. Indian J. Hort. 29:265-268

Nerson, H., H.S. Parks, Z. Karchi, and M. Sachs. 1985 Seed treatments for improved germination of tetraploid watermelon. HortScience 20:897-899.

SAS Institute. 1990. SAS user's guide: Statistics (6th ed.). SAS Inst., Cary, N.C. 